\author{
MAREK ŁUKASIK \\ Pomeranian University in Słupsk, Poland \\ marek.lukasik@apsl.edu.pl
}

\title{
A SHORT HISTORY OF POLISH-UKRAINIAN TERMINOGRAPHY
}

\begin{abstract}
Specialised dictionaries fulfil a plethora of linguistic and cognitive functions in specialised communication. In particular, such reference works help introduce, harmonise and standardise national terminologies, thus playing an indispensable role in disseminating high quality specialised knowledge. An even more important role may be attributed to bilingual and multilingual specialised dictionaries, whose primary goal is to facilitate the flow of scientific and technical information at an international level. This function has come to the fore in today's multinational and interconnected professional world. In light of the developing and ever stronger cooperation between Poland and Ukraine, an attempt is being made to evaluate bilingual and multilingual terminographic works containing Polish and Ukrainian which have been published in Poland to date. The aim is to assess the positive developments and to identify the gaps in Polish-Ukrainian terminography. It is hoped that the findings presented in this paper will be applied by terminographers in order to compile terminological dictionaries of higher quality, which satisfy the needs of specific users and follow terminographic principles.
\end{abstract}

Keywords: bilingual dictionary; multilingual terminography; terminographic analysis; metalexicography; terminological dictionary; Polish-Ukrainian terminography

\section{Introduction}

Undeniably, one of the most universal means of specialised knowledge transfer is the concept of language for specific purposes (LSP), in particular terminologies of various fields of human activity. Successful international cooperation between specialists requires a common language, which - from the terminological perspective - means either turning to one of the world languages, usually English, or using one of the languages of the communication partners. The most essential prerequisite for a successful transfer of professional information is that the language tool used to convey it must not distort the content. This also applies to terminological dictionaries, which are the most compact and comprehensive tools for intra- and interlingual knowledge transfer (Eukasik, 2014). Terminographic works of high quality are those compiled with the above principle in mind, fine-tuned to the characteristics and precision requirements of a discipline, as well as being tailored to the needs of its future users and following the fundamental principles of dictionary compilation.

Most, if not all, of the above conditions most probably still remain within the sphere of theoretical desiderata: all too often, new dictionaries exhibit the same errors and deficiencies as those already published, which leads to the sad conclusion that modern lexicographers (and equally terminographers) are unable to identify the strengths and weaknesses of their own field, 
learn from the mistakes of others, or implement new solutions. The general impression of a copyand-paste culture prevails. This negative trend is strengthened by publishers themselves, who are not particularly interested in novel lexicographic solutions (Piotrowski, 2001, pp. 62-63) or high dictionary quality (Tarp, 2012, pp. 125-126). However, the modern theory of terminography envisages the analysis and evaluation of existing specialised dictionaries, with the aim of obtaining meaningful guidelines or directives for future terminographic works (Bergenholtz \& Tarp, 1995, p. 31). Terminographic analysis is a research procedure that aims at a comprehensive study of existing terminographic works, allowing both general assessment of the state of terminography in a particular country or region, and a more detailed study of specific dictionary types or even individual dictionaries (Eukasik, 2007, 2010, pp. 26-34). The final aim is applicative: to produce ever better terminographic works. The procedure in question was used to evaluate terminological dictionaries in Polish and Ukrainian against a set of macro- and microstructural parameters. The results of the study are presented in the subsequent sections of this paper, while detailed analysis of the data is included in the Addendum.

\section{An Historical Outline}

Since the fall of communism in Poland in 1989 and Ukraine's regaining of independence in 1991, political, economic, scientific, professional and social ties between the two counties have been strengthening (Kuspys, 2008). The two neighbouring countries have also quickly become partners in a variety of cross-border undertakings (Shcherba, 2013). All such endeavours include a vigorous exchange of professional knowledge.

Although neighbours geographically, the two nations are divided linguistically, which can hinder mutual cooperation. Despite some major lexical similarities between Polish and Ukrainian, the main communication obstacle, especially for the younger generation of Poles, is the usage of a variant of the Cyrillic script in Ukrainian. On the other hand, the older generation, even if more acquainted with Russian, ${ }^{1}$ and hence being able to understand Ukrainian, may be overwhelmed by the rapid changes occurring in both languages, for example by the great number of Anglicisms in specialised languages (both Polish and Ukrainian) and the recent development of Ukrainian terminology. The tools that could help bridge this communication gap are terminological dictionaries in Polish and Ukrainian. Yet, as the general opinion holds, these are scarce and of poor quality (see below for detailed study results).

This lack of terminographic works may be a consequence of the rather short history of PolishUkrainian terminography, dating back to the year 1994, when the first terminological dictionary was published, namely S. Domagalski's Praktyczny polsko-rosyjsko-ukraiński słownik ekonomicznohandlowy (Warszawa, 1994). Moreover, it was not until 1999 that the first terminological dictionary in Polish and Ukrainian was released in Ukraine, ${ }^{2}$ i.e. A.В. Василюк, Нові педагогічні поняття: англо-польсъко-украӥнсъкий словник (Ніжин, 1999).

The lack of terminographic activity prior to 1991 may be a direct result of the totally different post-WWI and post-WWII political situations in Poland and Ukraine, the former being an independent state, although in the Soviet sphere of influence, and the latter becoming the Ukrainian Soviet Socialist Republic in 1919. Throughout the period 1919-1991 Ukrainian lexicography lived through times of revival (1917-1927), and suppression (1930s). The events of the 1930s were particularly harsh for lexicographers in Ukraine, which is why Rudnickyj does not hesitate to summarise them as a 'pogrom of Ukrainian lexicography', with systematic persecution of lexicographers undertaken within general purges of the Ukrainian Academy of Sciences, including the Institute of Ukrainian Scientific Language in Kiev (Rudnickyj, 1991, p. 2331). This was a severe setback for specialised lexicography, as the Institute had planned to publish around 100

\footnotetext{
${ }^{1}$ Mainly on account of obligatory classes of Russian in primary and secondary education until the beginning of the 1990s.

${ }^{2}$ According to the author's own review of catalogues of the National Library of Ukraine.
} 
terminological dictionaries (Ruda, 2012, p. 19; Komova, 2003, p. 7). Essentially, the situation did not change until the 1950s, and functionally until 1991.

Meanwhile, Polish terminography flourished. By way of example: between 1945 and 1989, over 200 terminological dictionaries in Polish and English were published, many of which were of high quality and internationally recognised (Czerni, 1977, pp. 49-50; Grzegorczyk, 1967, p. 7). Besides, neither Polish nor Ukrainian is - for the majority of fields - the so-called Primary Terminological System, ${ }^{3}$ i.e. terminological system in which specialist knowledge can be conveyed to the highest degree of precision (Lukszyn \& Zmarzer, 2006, p. 60ff), which might have influenced lexicographers' choices.

\section{Methodology}

As has been mentioned above, the methodology that allows the most comprehensive evaluation of existing terminological dictionaries is terminographic analysis. For the present study, partial, general and detailed terminographic analysis of terminological dictionaries in Polish and Ukrainian published in Poland ${ }^{4}$ since 1945 has been undertaken.

The study involved the following stages:

- bibliographic queries of the online and traditional library catalogues of the National Library of Poland (http://alpha.bn.org.pl) and metacatalogues: NUKAT (http://www.nukat.edu.pl) and KaRo (http://karo.umk.pl/Karo/) in Poland,

- bibliographic queries of online library catalogues in Ukraine (National Library of Ukraine http://www.nbuv.gov.ua),

- a review of existing bibliographies,

- the creation of a dictionary database,

- a quantitative analysis of the data,

- a qualitative evaluation of the dictionaries.

Qualitative analysis concerned the following dictionary parameters:
(a) thematic scope,
(b) directionality,
(c) size,
(d) projected users and dictionary functions,
(e) macrostructure type,
(f) microstructure composition,
(g) appendixes, addenda and other features etc.

To obtain precise qualitative data, a strict procedure was introduced with a view to evaluating the macro- and microstructural parameters of the TDs in question. As well as the main body of the dictionary, the analysis looked at additional materials, including introductions, users' manuals, publisher's notes, descriptions on dust covers, etc. A total of 22 terminological dictionaries published in a traditional (book) form in Poland underwent detailed terminographic analysis. ${ }^{5}$ The results of the analysis appear in the following paragraphs, as well as in the final section (Addendum) of the present paper. Important as they may be, online specialised dictionaries have been excluded from the analysis on account of their poor quality and lack of documentation. ${ }^{6}$

\footnotetext{
${ }^{3}$ According to a bibliographic study performed by the author of the present paper, the primary source language for Ukrainian multilingual terminographic works is Russian and English (published in Ukraine), while for Polish it is English.

${ }^{4} \mathrm{On}$ account of the poor availability of such works in Poland, and the limitations of this paper, a qualitative analysis of terminological dictionaries in Polish and Ukrainian published in Ukraine is yet to be performed.

${ }^{5}$ One TD came with an accompanying CD-ROM ${ }^{[10]}$. However, the electronic medium was not analysed.

${ }^{6} \mathrm{~A}$ notable exception, although in the area of general e-lexicography, is Polsko-ukrainski stownik elektroniczny (n.d.) - a result of a joint project of the Institute of Slavic Studies of the Polish Academy of Sciences and the
} 


\section{Terminographic Analysis}

\subsection{General terminographic analysis and quantitative study}

Based on a bibliographic analysis of the data collected as a result of queries of online library catalogues (see above), it is possible to state that Polish-Ukrainian terminography is far from thriving. In the years 1945-1993, not a single specialised dictionary in Polish and Ukrainian was published, either in Poland or in Ukraine. General language dictionaries were equally scarce, with only a few titles published throughout the period. It may be said that Polish-Ukrainian terminography emerges only in the 1990's, with the first dictionary published in 1994 (see [1] ${ }^{7}$ ). In the years 1990-2015, a total of 22 TDs in Polish and Ukrainian were published in Poland, while only 14 such publications were released in Ukraine ${ }^{8}$ in the same period. Table 1 presents the number of TDs published in Poland and Ukraine between 1990 and 2015.

Table 1: Terminological dictionaries in Polish and Ukrainian published in Poland (PL) and Ukraine (UKR) between 1990 and 2015

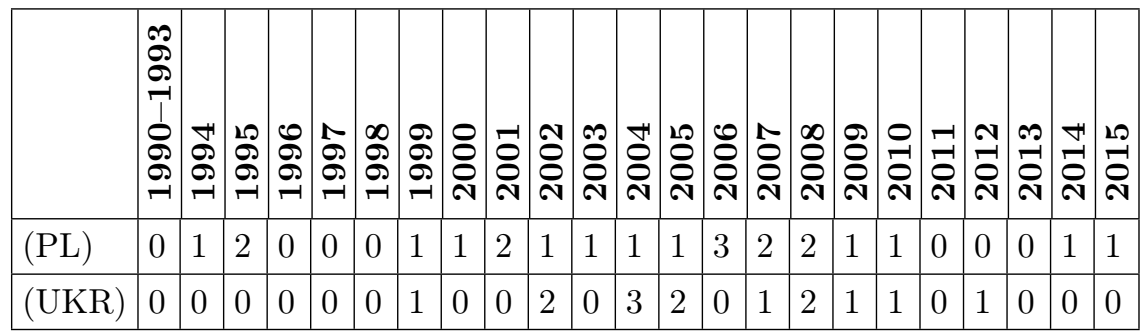

Of the 22 TDs published in Poland, 21 works came only in one edition. The only entirely reprinted dictionary is S. Domagalski's Wielki słownik polsko-ukraiński, ukraińsko-polski: z rozszerzona terminologia wspótczesnego biznesu: 200000 wyrażeń (Warszawa 2008 ${ }^{[17]}, 2014^{[21]}$ ). The dictionary was also published in Ukraine (Тернопіль 2010) as an identical copy ${ }^{9}$ of the Polish edition.

Two other dictionaries by Domagalski deserve particular attention, namely Praktyczny polskorosyjsko-ukraiński słownik ekonomiczno-handlowy (Warszawa 1994 ${ }^{[1]}$ ), and Praktyczny słownik polsko-rosyjsko-ukraiński: ekonomika i handel: z indeksami terminów rosyjskich $i$ ukraińskich (Warszawa 2000[5]). Despite having different numbers of terms (15,000 and 32,000, respectively), and the inclusion of indexes in the latter, the two works have a lot in common, in particular as regards to terminology presentation, definitions, and addenda content. Therefore, at least from the lexicographic point of view, they could be viewed as two editions of the same work (the latter obviously being a corrected and enlarged one).

Two other dictionaries strongly linked with each other are: Terminologia kościelna: mały słownik opisowy polsko-ukraiński i ukraińsko-polski (Poznań 1995 ${ }^{[3]}$ ) and Popularny słownik sakralizmów polskich i ukraińskich (Poznań 2001 ${ }^{[7]}$ ). Compiled by the same authors, A. Markunas and T. Uczitiel, the two works share not only the same scope of terminology content, but also macroand microstructural characteristics.

Ukrainian Lingua-Information Fund at the National Academy of Science of Ukraine (available at: http://www . domeczek.pl/ polukr/pus/index.php).

${ }^{7}$ The numbers in square brackets refer to the records of the database, presented in this paper chronologically in a simplified form (textual format). See Addendum.

${ }^{8}$ The numbers presented should be viewed as an approximation. Despite the author's greatest effort to provide complete data, it is possible that some omission might have occurred, due to the fact library resources may be incomplete.

${ }^{9}$ As regards the content of the main body. Otherwise, the dictionary had been 'localised', or adapted to the Ukrainian publishing market. 
Sometimes, dictionaries may appear in various countries as 'language versions', presenting the same lemma stock, yet with the outside matter - and sometimes the arrangement of entries - adapted to the needs of the local users (cf. the above example of S. Domagalski's work published Ukraine). This is certainly not the case with A. Vasilûk and M. Tarnaś's Leksykon pedagogiczny angielsko-polsko-ukrainski (Płock 2006 ${ }^{[13]}$ ). Although the authors themselves admit that the dictionary is 'the latest version' of the two previous dictionaries by A. Vasilûk, namely Нові педагогічні поняття: англо-польсъко-украӥнсъкий словник (Ніжин 1999) and Педагогічний словник-лексикон. Англо-украӥнсъкий. Украӥнсъко-англійсъкий (Ніжин 2004), it cannot be viewed as one: the extensive changes made, and the use of a number of Polish sources, render the work an original undertaking, rather than merely a new edition of a dictionary.

Detailed terminographic analysis revealed that three dictionaries published between 2006 and 2008 make up a series of learner's dictionaries: two works by W. Kozubel, i.e. Stownik terminów biologicznych ukraińsko-polski i polsko-ukrainski (Warszawa 2006 ${ }^{[12]}$ ) and Słownik terminów chemicznych ukraińsko-polski $i$ polsko-ukraiński (Warszawa 2007 ${ }^{[15]}$ ), and a one by W. Halan, Stownik terminów informatycznych ukraińsko-polski i polsko-ukrainski (Warszawa $2008^{[18]}$ ). These are the only specialised dictionaries listed as supplementary reference works in the core curriculum for junior-high schools and high schools in Poland with Ukrainian as the language of instruction. ${ }^{10}$

Beyond official publications, the compilation of terminological glossaries or small dictionaries takes place as part of research into Polish-Ukrainian terminology at university level, often within the framework of MA or PhD projects. For example, some MA projects at the Institute of Ukrainian Studies, University of Warsaw, have involved the compilation of Ukrainian-Polish and/or Polish-Ukrainian specialised glossaries. According to the head of the Institute, Professor Irena Mytnik, in 2015 terminographic work within MA projects concerned the terminologies of inheritance law, criminal law, medicine, tourism and logistics. More extensive and advanced research has been undertaken as part of $\mathrm{PhD}$ projects, with two major bilingual and bidirectional terminographic works on legal terminology and gynaecology soon to be published (Mytnik, 2015, private correspondence). Similar work has been done at other universities, including The John Paul II Catholic University of Lublin, ${ }^{11}$ Maria Curie-Skłodowska University in Lublin or the University of Wrocław. ${ }^{12}$ The works were not part of the present study on account of their limited scope and impact on the entire dictionary market and, therefore, will not be discussed here.

The present study concerns solely dictionaries whose scope explicitly refers to the terminology of a certain discipline. Naturally, general dictionaries also include terminology, depending on the extent to which terms of a given discipline have permanently permeated into the general language. However, the choice of terms in general-language dictionaries to a large degree depends on the size of the work (the bigger the size, the more space for terminology) as well as an adherence to objective methods of lemma selection (i.e. use of corpora, enabling the extraction of significant terminological units).

One example of a general-language dictionary that includes a significant number of terminological items is Słownik tematyczny polsko-ukrainski (Kononenko, Mytnik, \& Wasiak, 2010/2015). The dictionary covers 30 thematic sections, some of which seem to be quite specialised, for example economics, business and finance, law and crime prevention, and the military. It has to admitted, however, that coverage of the specialised areas is limited, which is justifiable given the universal nature of the work and its wide target audience. Undeniably, general language dictionaries will always prove useful in the educational context, provided that they have been compiled in accordance with the art of dictionary compilation.

\footnotetext{
${ }^{10}$ Ministry of Education (Ministerstwo Edukacji Narodowej, n.d.).

${ }^{11}$ For example, Master's theses: E. Czobot's Terminologia ekonomiczna we wspótczesnym języku ukrainskim (Czobot, 1999), A. Barwiak's Terminologia ekonomiczna we wspótczesnym ukraińskim języku literackim (Barwiak, 2005), D. Kępa's Wspótczesna terminologia ukraińska z zakresu prawa międzynarodowego (Kępa, 2005) or A. Pliszka's Charakterystyka strukturalno-semantyczna terminologii prawniczej w języku polskim i ukraińskim (Pliszka, 2010).

${ }^{12}$ For example, P. Jóźwikiewicz's Lingua Ucraina ad res informaticas pertinens. Studium nad ukraińskim słownictwem informatycznym (Jóźwikiewicz, 2013).
} 


\subsection{Detailed terminographic analysis}

\subsubsection{Terminology coverage}

One of the major parameters in an analysis of a national terminographic output is the scope of the terminology presented in the works under investigation. Such study helps to establish which fields require the publication of a terminological dictionary ${ }^{13}$ and allow an overview of the dominant areas of existing (or past) cooperation. Table 2 and Table 3 present specialised fields whose terminologies were covered by TDs published in Poland and Ukraine respectively.

Table 2: Terminologies of specialised fields covered by TDs in Polish and Ukrainian published in Poland

\begin{tabular}{|l|c|l|}
\hline \multicolumn{1}{|c|}{ Field(s) covered } & No. of TDs & \multicolumn{1}{c|}{ Publication year } \\
\hline administration & 2 & $2004^{[10]}, 2009^{[19]}$ \\
\hline biology & 1 & $2006^{[12]}$ \\
\hline business & 3 & $1995^{[2]}, 2002^{[8]}, 2008^{[17]}, 2014^{[21]}$ \\
\hline chemistry & 2 & $2007^{[15]}, 2007^{[16]}$ \\
\hline economics & 2 & $1994^{[1]}, 2000^{[5]}$ \\
\hline information technology & 1 & $2008^{[18]}$ \\
\hline journalism & 1 & $2015^{[22]}$ \\
\hline linguistics & 1 & $2005^{[11]}$ \\
\hline literary studies & 1 & $2010^{[20]}$ \\
\hline machining & 1 & $2001^{[6]}$ \\
\hline medicine & 2 & $1999^{[4]}, 2003^{[9]}$ \\
\hline oil refining & 1 & $2007^{[16]}$ \\
\hline pedagogics & 1 & $2006^{[13]}$ \\
\hline police and legal terminology & 1 & $2006^{[14]}$ \\
\hline religious studies & 2 & $1995^{[3]}, 2001^{[7]}$ \\
\hline Trade & 2 & $1994^{[1]}, 2000^{[5]}$ \\
\hline
\end{tabular}

The data seem to support the general opinion that the main area of cooperation between Poland and Ukraine concerns business, trade, and economics. With standardisation of terminology being one of the top priorities, it comes as no surprise that dictionaries of chemistry are so popular, in particular in the educational context.

However, taking into account the large number of scientific or technical fields, not to mention the number of various professions or areas of human interest and the existing areas of cooperation between Poland and Ukraine, the lists above are at best modest. These areas of cooperation can easily be tracked, based on import/export data between the two countries as well as government agreements and cross-border cooperation programmes. These include (in alphabetical order): administration, agriculture, aircraft parts (jet engines, gas turbines), architecture and construction, border infrastructure, the chemical industry, copyright law, cultural cooperation, education, electro-mechanics, energy carriers (oil, gas), energy infrastructure, environmental protection, European integration, the exchange of trade and legal information, food production, intellectual and

\footnotetext{
${ }^{13}$ Given that extra-linguistic factors, such as the extent and fields of cooperation, are also analysed.

${ }^{14}$ The number of TDs presented in this table do not add up to the total of 22 TDs analysed, as some dictionaries include terminology of more than one field.
} 
Table 3: Terminologies of specialised fields covered by TDs in Polish and Ukrainian published in Ukraine

\begin{tabular}{|l|c|l|}
\hline \multicolumn{1}{|c|}{ Field(s) covered } & No. of TDs & Publication year \\
\hline business & 1 & 2010 \\
\hline chemistry & 3 & $2004,2005,2005$ \\
\hline economics & 1 & 2004 \\
\hline finance \& accounting & 1 & 2004,2008 \\
\hline general science \& technology & 2 & 2008,2009 \\
\hline hydraulics & 1 & 2002 \\
\hline Law & 1 & 2004 \\
\hline linguistics & 1 & 2004 \\
\hline medicine & 1 & 2002 \\
\hline pedagogics & 1 & 1999 \\
\hline sanitary technology & 1 & 2002 \\
\hline sports & 1 & 2012 \\
\hline Trade & 1 & 2004 \\
\hline
\end{tabular}

property law, light industry, local development, logistics, machining equipment, metallurgy, the mineral industry, NGOs, the paper industry, recreation, scientific cooperation, timber production, the tobacco industry, tourism, transport systems (infrastructure), transportation (incl. railways, air transport), urban planning, and vocational training (Kuspys, 2008; Shcherba, 2013; Polish Press Agency, 2014; PL-BY-UA 2007-2013, n.d.).

This list certainly points to the areas that require terminological studies and the publication of a terminological dictionary. Admittedly, it is English that has become the global language of science and technology, yet for cross-border cooperation bilingual TDs in the languages of the partners, or multilingual TDs in both languages plus English and possibly Russian seem to be the most efficient solution (see below).

\subsubsection{Users and dictionary functions}

A more comprehensive picture can be obtained by comparing the above lists of fields covered by TDs with the prospective users the dictionaries are aimed at. These include (numbers in parentheses indicate the number of TDs naming its addressees):

(a) professionals and specialists (including managers, trade partners, academics, business people, medical doctors, police officers; 17 ),

(b) students (8),

(c) pupils (4),

(d) believers (2),

(e) translators (1),

(f) civil society (1).

Besides the obvious user group of professionals in their fields, it is clear that the educational aspect cannot be overlooked and that more attention should be paid to it. Following qualitative evaluation of the TDs published in Poland, it has to be admitted that few dictionaries meet the criteria of a learner's dictionary. Extensive lexicographic work is needed to fill the gap, all the more so as schools with Ukrainian as the language of instruction expect more pupils following the 
recent rise in Ukrainian immigration to Poland (Goetting, 2015). Polish universities also expect more Ukrainian students following Ukraine's admission to the Erasmus + Programme.

The above considerations seem to be confirmed by the rationale for compiling TDs, as outlined by their authors. Not surprisingly, a lack of dictionaries in the field is the most frequently cited reason for deciding upon the compilation of a specific dictionary, followed by the specific needs of users, such as a lack of tools that would help improve professional communication, a lack of teaching materials in the field, or a lack of terminology systematisation tools.

Together with the intended dictionary users, dictionary functions, which are usually explicitly declared by their authors/editors in introductions or on dust covers, are of utmost importance when undertaking an evaluation of any terminographic work. Such lists of functions constitute a benchmark against which the structure and content of a dictionary can be evaluated. Table 4 presents general and specific functions which the TDs analysed are supposed to fulfil.

Table 4: Functions of TDs in Polish and Ukrainian published in Poland between 1994 and 2015

\begin{tabular}{|l|c|}
\hline \multicolumn{1}{|c|}{ Dictionary functions (help in or tool of) } & No. of TDs \\
\hline translation (of economic and trade-related texts) & 5 \\
\hline reading professional literature & 4 \\
\hline maintaining cooperation with international partners & 3 \\
\hline establishing and widening of trade cooperation & 2 \\
\hline preparation of papers/texts for publishing abroad & 2 \\
\hline preparation for didactic and research work & 2 \\
\hline expanding users' metalanguage & 2 \\
\hline (international) systematisation of terminology & 1 \\
\hline maintaining communication between academics and specialists & 1 \\
\hline preparation to an interview & 1 \\
\hline learning a subject & 1 \\
\hline teaching a subject & 1 \\
\hline getting to know professional vocabulary of the neighbours & 1 \\
\hline getting to know literary and cultural phenomena & 1 \\
\hline filling the terminological gap within East-European languages & 1 \\
\hline exchange of communications & 1 \\
\hline characterisation and systematisation of phenomena & 1 \\
\hline building democracy & 2 \\
\hline proceeding with European integration; & 1 \\
\hline
\end{tabular}

The data presented above seem to confirm that the dictionary market attempts to satisfy user needs. However, two things have to be borne in mind. First and foremost, there are no scientific user studies in the area of Polish-Ukrainian terminography. Neither are such studies undertaken by publishers themselves, which becomes evident in light of the claimed multi-functionality of most terminographic works. Secondly, listing dictionary functions is one thing, but realising them in the actual work is another. Therefore, any evaluative comment concerning dictionary functions would have to be viewed as a generalisation based on projected universal user needs and a comparison of concrete dictionary parameters to the parameters of terminographic models. Such evaluation has not been carried out within this study. 


\subsubsection{Directionality}

In bi- and multilingual TDs, directionality can reveal the path of specialist knowledge transfer if the dictionary is primarily passive, or at least bifunctional. According to the data gathered, 11 TDs (i.e. $50 \%$ of the total) are bidirectional, i.e. Polish-Ukrainian / Ukrainian-Polish $\left(1995^{[2]}, 1995^{[3]}\right.$, $2001^{[7]}, 2002^{[8]}, 2003^{[9]}, 2004^{[10]}, 2006^{[12]}, 2007^{[15]}, 2008^{[17]}, 2008^{[18]} ; 2014^{[21]}$ ), while 9 TDs $(41 \%)$ are multilingual $^{15}\left(1994^{[1]}, 1999^{[4]}, 2000^{[5]}, 2001^{[6]}, 2006^{[13]}, 2006^{[14]}, 2007^{[16]}, 2009^{[19]}, 2010^{[20]}\right)$. Surprisingly, unidirectional dictionaries are rare, with only one Ukrainian-Polish $\left(2005^{[11]}\right)$ and one Polish-Ukrainian TD $\left(2015^{[22]}\right)$ published to date, representing $4.5 \%$ each.

Multilingual TDs deserve additional attention as the directionality and inclusion of other languages can reveal specific dictionary functions and extra-linguistic facts. The multilingual works analysed include three $\left(4 \mathrm{TDs}^{[1,4,5,13]}\right)$, four $\left(2 \mathrm{TDs}^{[16,20]}\right)$, five $\left(2 \mathrm{TDs}^{[14,19]}\right)$ and eight $\left(1 \mathrm{TD}^{[6]}\right)$ languages. The languages included in the multilingual TDs have been presented in Table 5. In seven out of the nine multilingual TDs, Polish is the source language, while in the remaining two cases it is English.

Table 5: Languages in multilingual TDs including Polish and Ukrainian published in Poland between 1994 and 2015

\begin{tabular}{|c|c|}
\hline Languages in multilingual TDs & No. of TDs \\
\hline ru & 6 \\
\hline en & 3 \\
\hline cs & 2 \\
\hline be & 1 \\
\hline lt & 1 \\
\hline fr & 1 \\
\hline de & 1 \\
\hline sk & 1 \\
\hline la & 1 \\
\hline
\end{tabular}

Naturally, Russian is the most frequent language included in the multilingual TDs analysed. On the one hand, this is influenced by the geopolitical position of Poland and Ukraine, as well as the historical ties of both countries with Russia. On the other hand, after years of Russian influence, the time had come for the establishment of a Ukrainian terminology (to replace the Russian one), and therefore the inclusion of Russian terms in a multilingual work is of both contrastive and communicative value. Overall, however, as seen in the above table the choice of other languages and a non-dominant role of English seem to suggest that the dictionaries analysed were produced for the local, East European market, rather than a global one.

\subsubsection{Dictionary size}

According to some theoreticians, the size of a terminological lexicon, i.e. the set of terms of a clearly-defined specialised field, does not exceed several thousand units (Lukszyn \& Zmarzer, 2006 , p. 143). Of course, some terminological fields vary in size, yet it may be assumed that a field-specific dictionary reflecting the size of a terminological lexicon should contain between 1,000 and 10,000 terms. If a dictionary contains fewer than 1,000 terms, it most certainly is incomplete when compared with the entire terminological lexicon. This does not mean that the work is of inferior quality: a small number of terms may occur (and be advantageous) in some specific dictionary

\footnotetext{
${ }^{15}$ Obviously including Polish and Ukrainian.
} 
types, such as, for example, subfield dictionaries, terminological standards or microthesauruses. Interdisciplinary terminological dictionaries, i.e. ones with terminology covering the major field plus some interrelated fields include from between 10,000 to a few dozen thousand terms. A multidisciplinary terminological dictionary, on the other hand, lists from a few dozen thousand terms to hundreds of thousands of terms. It has been claimed, therefore, that dictionary size can in fact be a useful guide for the users when assessing the comprehensiveness of the dictionary. Undeniably, a lot depends on the lemma selection procedure and the quality of the terms themselves. Dictionary publishers do realise that and, therefore, possibly for marketing reasons, do not reveal the details of their in-house terminographic methods or sources of terminology. They even cite inaccurate figures as regards to the number of entries in bi- or multilingual TDs, often referring to the overall number of terms, i.e. entry terms and their foreign language equivalents.

According to the data obtained as a result of the terminographic analysis, most of the dictionaries analysed contain between 1,000 and 10,000 terms, reflecting to a lesser or greater degree the boundaries of a terminological lexicon and confirming the general attempt of the authors/editors/publishes to meet the basic need of reasonable coverage. As has been mentioned above, dictionaries of fewer than 1,000 words either relate to narrow subdomains, have specific functions, are of a specific type, or must be regarded as incomplete. Full content analysis based on corpus research is needed to compare the completeness of the dictionary lemma stock with the extent of terminology comprising the terminological lexicon. However, caution is necessary as the extent of the terminological lexicon is not a simple register derived from frequency lists: terminologies of various disciplines form more or less structured terminological systems whose boundaries may be more or less blurred. Thus, for terminographic purposes, and especially for the corpus-based assessment of the completeness of any terminological dictionary, quantitative terminological analysis of the corpus (ideally, compiled separately for each dictionary) must be paralleled with a conceptual study of the lexicon and user needs studies.

Table 6: Languages in multilingual TDs including Polish and Ukrainian published in Poland between 1994 and 2015

\begin{tabular}{|l|c|c|c|c|c|}
\hline & $<\mathbf{1 0 0 0}$ & $\mathbf{1 k}-\mathbf{1 0 k}$ & $\mathbf{1 0 k}-\mathbf{4 0 k}$ & $\mathbf{4 0 k}-\mathbf{1 0 0 k}$ & $>\mathbf{1 0 0 k}$ \\
\hline No. of TDs $(\Sigma=21)$ & 3 & 14 & 3 & 2 & 0 \\
\hline
\end{tabular}

\subsubsection{Type of macrostructure}

Macrostructure type is defined as the arrangement of entries in a dictionary, which can be based on the formal characteristics of the language sign, e.g. its orthographic properties (alphabetical order), the semantic properties of the language sign (systematic/thematic order) or extrinsic criteria, e.g. frequency (frequency order). Alphabetic arrangement is by far the most popular, on account of its practicality, objectivity and intersubjective nature (Bańko, 1988, p. 57; Bogusławski, 1988, p. 61). It holds true for both general-language and specialised dictionaries, although compared to the former, the latter are more frequently ordered systematically. This higher popularity of systematic arrangement in TDs is most probably a consequence of the traditional approach to terminography, as proposed by the Vienna School of Terminology (cf. Felber \& Budin, 1994) and followed by dictionary makers for decades. It has been claimed that such a macrostructure better represents the structure of specialist knowledge (Michta, 2014, pp. 191-192), and is also best suited for didactic dictionaries, aimed at facilitating the teaching-learning process (Lukszyn, 2010, p. 92). It is also a convenient structure in dictionaries aiming at the international systematisation of terminology.

According to the analysis of the TDs in Polish and Ukrainian published in Poland between 1994 and 2015, the majority of works, i.e. 19 TDs (86\%) follow alphabetic lemma arrangement, while the remaining two $(9 \%)$ are of systematic ${ }^{[6]}$ and thematic arrangement ${ }^{[10]}$. The small number 
of dictionaries using systematic arrangement is not surprising, as the compilation of such works requires much more time and a high degree of expertise, both in the sphere of subject-matter and terminological/terminographic expertise, compared to the relatively simple and automatically generated alphabetical order. Compiling systematic/thematic works might not be appealing to commercial publishing houses, which focus on a relatively quick return on investment. Additionally, based on the potential fields of Polish-Ukrainian cooperation, one can easily reach the conclusion that the market for Polish-Ukrainian specialised dictionaries is insatiable, and anything published will quickly disappear from bookshops. This, unfortunately, promotes low quality and simple lexicographic solutions. More elaborate terminographic techniques, such as systematic macrostructures, and possibly some form of experimentation, are expected to follow a period of a terminographic boom, i.e. a rapid growth in the number of TDs (also of poor quality) in a variety of fields as a response to the observed high dictionary demand. In the opinion of the author, as regards Polish-Ukrainian terminography, this is yet to come. Undeniably, one group that will certainly benefit from more advanced terminographic techniques will be learners and teachers of Polish and Ukrainian specialised languages.

\subsubsection{Other components of the outside matter}

Bibliography Including a list of references in dictionaries is regarded as an element of good practice. In terminographic works it is of primary importance, as it helps to establish the quality of terminological resources, including their normative character, their currency, and the scope of the ter-

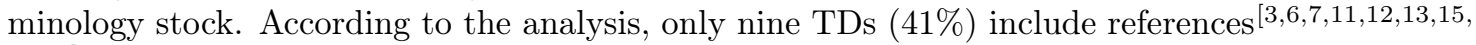
${ }^{20,22]}$. Qualitative analysis shows that no dictionary is based on corpus data, while only three TDs cite terminological standards as one of the sources of terminology ${ }^{[6,15,16]}$.

Indexes Indexes are elements of dictionary access structure, helping users find the required information within an appropriate entry. Indexes are obligatory content-organising lists in systematic and thematic mono- bi- and multilingual dictionaries, and may be optional in bi- and multilingual alphabetic dictionaries, enhancing, however, dictionary functionality by enabling multilingual term searches. Of course, there are several other types of indexes, for example indexes of term elements, standardised names, descriptors, ascriptors or antonyms. However, their use in terminological dictionaries seems to be marginal.

Detailed terminographic analysis revealed that six TDs contain an index ${ }^{[5,6,10,16,20,22]}$, out of the total of 11 TDs that would surely benefit from inclusion of one. ${ }^{16}$ Admittedly, the two dictionaries with systematic macrostructure do include indexes ${ }^{[6,10]}$, although in the case of the former dictionary, i.e. Basic terminology on machining with tools of defined wedge geometry: in eight languages ${ }^{[6]}$, the index is of limited use: the dictionary includes eight languages, English, Polish, French, German, Russian, Ukrainian, Czech and Slovak, while the index contains terms of only the first two. It may be a result of the specific design of the work, in which definitions are also only presented in Polish and English, suggesting a specific, limited circle of users (Poles). The lack of other language indexes in this systematic dictionary limits its functionality and contradicts the authors' assurance that the work is designed to be of assistance in reading "rich foreign language" and in preparing "a publication for international presentation and promotion" (Wójtowicz, Górska, Przybylski et all, 2001, p. 21). Due to the lack of appropriate indexes, it is virtually impossible to use the dictionary as an aid in reading literature other than that in English or Polish.

Two TDs include indexes in the form of bilingual miniglossaries, i.e. Russian-Polish and Ukrainian-Polish in Praktyczny słownik polsko-rosyjsko-ukrainski: ekonomika $i$ handel ${ }^{[5]}$, and Ukrainian-Polish in Polsko-ukraiński słownik terminów dziennikarskich: z suplementem ukraińskopolskim $^{[22]}$. Such a solution reduces the time required for searches, in particular for translators who sometimes do not need extended information to be included in the entry proper. One multilingual TD, i.e. Angielsko-polsko-rosyjsko-ukraiński słownik z chemii i technologii ropy naftowej ${ }^{[16]}$,

\footnotetext{
${ }^{16}$ Terminological dictionaries that would benefit from including an index are: $[1,4,13,14,19]$.
} 
includes indexes of equivalents in all the target languages of the dictionary. A surprising solution has been adopted in Polsko-czesko-rosyjsko-ukrainski słownik pojęć literackich ${ }^{[20]}$, which lists only the main Polish headwords in the index, that is around 1,900 terms out of the total of 4,000 entries. Such a composition greatly restricts the usefulness of the work.

Alphabets Since Polish and Ukrainian use different scripts, dictionaries often include alphabets of the languages to help users cope with the sequence of letters in an alphabetic entry arrangement. In the present study, $11 \mathrm{TDs}^{[2,5,10,11,12,13,15,16,17,20,21,22]}$ add alphabets, of which six TDs $^{[2,10,12,15,17,22]}$ include alphabets of both Polish and Ukrainian, one TD ${ }^{[11]}$ presents only the Ukrainian set of letters, while four TDs ${ }^{[5,13,16,20]}$ print alphabets of more than the two languages, i.e. (i) Polish, Ukrainian and English ${ }^{[5,13]}$, (ii) English, Polish, Russian and Ukrainian ${ }^{[16]}$ and (iii) Polish, Czech, Russian and Ukrainian ${ }^{[20]}$.

Addenda Various appendixes to terminological dictionaries enhance the usefulness of the works, most frequently in the educational context. Of the 21 TDs investigated, six TDs offer an addendum of some kind. Two of the TDs analysed include appendixes that are closely related to the topical specialised area, namely (i) a list of base and derivative SI units, a list of prefixes of the power of ten and a list of standardised names of elements in Polish and Ukrainian, in a dictionary of chemical terminology ${ }^{[15]}$, and (ii) basic prayers in Polish and Ukrainian, in a dictionary of religious studies $^{[3]}$. The other four TDs, all authored by S. Domagalski, are devoted to the terminology of business and include addenda that might prove helpful in everyday communication. They include lists of names of world currencies, names of countries and capitals, glossaries of geographical names, numerals and names of weekdays, all presented in a parallel fashion, i.e. Polish/Ukrainian ${ }^{[8,17,21]}$ or Polish/Russian/Ukrainian) ${ }^{[5]}$.

\subsubsection{Components of microstructure}

Depending on the intended functions and user needs, the number and type of microstructural (=entry) components may vary. The minimum is the entry term itself, as in the case of spelling dictionaries, accompanied by foreign language equivalents in bi- and multilingual glossaries. In fact, the components range from content organisation elements (such as entry number and various labels, for example grammatical, lexicographic, terminological labels or indications of which subject area a term belongs to), through a number of linguistic and/or terminological characteristics (orthographic variants, inflectional paradigm, transcription, transliteration, morphological structure, etymology, collocations, register, formal terminological status, etc.) to term explication and illustration methods (sense disambiguation, definitions, citations, semantic relations, foreign language equivalents, pictures etc.) and bibliographical data.

Taking into account the fundamental rules of terminographic work, including the prerequisite of undistorted knowledge transfer and the primacy of users' needs, as well as characteristics of both languages in question, i.e. Polish and Ukrainian, the microstructures of all TDs were analysed against the parameters that are most salient from the research perspective taken.

Term explication A fundamental component of each terminological dictionary entry is the explication of a term (concept). In bi- and multilingual terminography terms may be explained in three ways: (a) by providing foreign language(s) equivalents (as in terminological glossaries); (b) by providing term definition/description in one or more languages plus foreign language(s) equivalents (as in explanatory terminological dictionaries), and (c) by illustrating term position in the terminological system of two or more languages (as in terminological thesauruses). Combinations of any two or more of the solutions cited above give rise to hybrid terminological dictionaries.

Terminology explication is a very important dictionary feature from the perspective of the user. In fact, bi- and multilingual terminological glossaries (i.e. non-definitional dictionaries) are designed for specialists, mainly because professionals are generally acquainted with the meaning 
of the terms in their own mother tongue, and therefore use dictionaries as repositories of foreign language equivalents. Alternatively, such works, especially multilingual TDs, can be used for the purpose of disseminating standardised international terminology. Conversely, it is acknowledged that didactic, or learner's, dictionaries should provide explication of terms in the form of a definition or description, plus some form of term use illustration.

According to the analysis, 13 dictionaries (59\% of all the TDs studied) provide only foreign language equivalents, and hence are terminological glossaries; four works $\left(18 \%^{[3,6,7,22]}\right)$ provide entry term definitions, and thus are explanatory dictionaries, while the remaining four TDs $\left(18 \%^{[1,5,10,13]}\right)$ provide definitions of only some terms, and are therefore hybrid dictionaries (glossary-explanatory subtype). Of the eight dictionaries providing explication, five provide definitions in a parallel fashion ${ }^{17}$ in all the languages of the dictionary (two in Russian, Polish and Ukrainian $^{[1,5]}$; three in Polish and Ukrainian ${ }^{[3,7,10]}$ ), one TD includes definitions in two languages, namely in English and Polish ${ }^{[6]}$, one bilingual dictionary includes definitions in Polish only ${ }^{[22]}$, and one trilingual TD, i.e. English-Polish-Ukrainian, includes definitions in Ukrainian only ${ }^{[13]}$. The definitions provided in the TDs researched are rather concise and none exhibited features of being encyclopaedic.

In certain cases, the illustration of term use (exemplary sentences/citations, corpus concordances) may prove equally important for the reconstruction of the meaning and linguistic behaviour of the term. However, only two TDs include illustrations of term use in context ${ }^{[1,2]}$.

When set against the projected target users and dictionary functions, and in particular the multi-functionality of the works, as claimed by their authors/editors, it is imperative to emphasise that from the perspective of the term explication parameter, most TDs do not meet the minimum requirements. According to the data presented in Table 4 above, most of the TDs investigated are supposed to be a translation aid. However, contrary to popular belief, a bi- or multilingual dictionary, and in particular a bi- or multilingual glossary, is rarely a good translation tool. Specialised translation dictionaries require a specific set of data useful to the translator, including sense disambiguation, definition, collocational data, grammatical information, usage notes, and comments based on contrastive analysis (especially in the case of culturally-dependent terminology), among other data. Unfortunately, none of the TDs analysed fulfils this function to the extent that would render the work a true translational tool. Another example is the declared didactic function of some TDs. Again, most of the dictionaries whose authors claim their work to be used as a resource by pupils/students are, in fact, glossaries ${ }^{[4,9,11,12,15]}$. This renders them of limited usefulness to the target group in question.

Grammatical information In dictionaries which present languages with complicated grammar, and in particular in bi- and multilingual dictionaries with languages exhibiting considerable differences, such as Polish and Ukrainian, providing grammatical information in the form of a label or a comment is a necessary measure. Nevertheless, only six TDs of all the dictionaries analysed (i.e. $27 \%$ ) provide information on grammatical gender, ${ }^{[2,4,11,14,20,22]}$, and do so to a varying extent: three TDs provide such information for all the languages of the dictionary (two for Polish and Ukrainian ${ }^{[2,11]}$ and one for Polish, Czech, Russian and Ukrainian ${ }^{[20]}$ ), one TD includes it for the entry term only (i.e. for Polish) ${ }^{[22]}$, one TD for the equivalents only (i.e. for Belarusian, Lithuanian, Polish and Russian) ${ }^{[14]}$, and one TD provides grammatical information for only one of the three languages of the dictionary (i.e. for Latin $)^{[4]}$. More complex grammatical information is found in three TDs, and includes word endings of the genitive, presented - again - to a varying extent: one provides it for all the languages of the dictionary, i.e. Polish and Ukrainian ${ }^{[11]}$, one for Polish, Czech, Russian and Ukrainian ${ }^{[20]}$, and one TD presents it for only the entry term, i.e. Polish ${ }^{[22]}$. Only one TD includes word endings of feminine and neuter of adjectives for the two languages of the dictionary (Polish and Ukrainian) ${ }^{[11]}$.

Similar observations can be made with regards to the word stress. On account of the sharp

\footnotetext{
${ }^{17}$ In respective language sections or in consecutive defining sections of the dictionary.
} 
differences between Polish and Ukrainian in this respect, this linguistic feature may pose a great challenge for learners of Ukrainian. Consequently, dictionaries for non-Ukrainians should include word stress marks for Ukrainian words. According to the study, only ten TDs (45\%) include stress for Ukrainian ${ }^{[2,3,7,11,12,14,15,19,20,22]}$, one of which also includes stress for Russian ${ }^{[19]}$, and two other provide stress marks for Belarusian, Lithuanian and Russian ${ }^{[14,19]}$.

A scarcity of grammatical information in terminological dictionaries seems to be a frequent deficiency in TDs in general (cf. Lukasik 2010, p. 193). However, as regards the language pair discussed in this article, more effort should be made by lexicographers/terminographers to meet the educational needs of dictionary users.

Terminological norms Based on the traditional view of terminology, terminological dictionaries should include only standardised specialised vocabulary items (=terms in the strict sense). According to the modern approach, one should not solely focus on standardisation, as specialised languages also include other heterogeneous vocabulary items alongside terms. Considering the nature of various fields of human activity, it comes without saying that for some disciplines standardisation is more warranted than for others.

Terminographic analysis has revealed that three of the TDs studied here include standardised terms: two in chemistry ${ }^{[15,16]}$ and one in technology ${ }^{[6]}$. In fact, based on the rather short list of fields included in Table 2, one can come to the conclusion that only a few other disciplines would require terminology standardisation (possibly biology or information technology).

At the other end of the professional vocabulary continuum are informal language units, such as professional slang expressions. From the perspective of in-group professional communication, such expressions play an important role and should not be excluded from the lemma list, yet only one TD is claimed by the authors to include slang expressions ${ }^{[14]}$.

However, no detailed analysis of lemma lists against existing terminological standards and/or up-to-date specialised corpora was performed by the author, and, therefore, no qualitative assessment of the degree to which this parameter is fulfilled by the TDs was possible. Nonetheless, taking into account the interdisciplinary nature of various fields of professional activity, a general terminographic directive would be to include all kinds of specialised vocabulary in TDs, standardised and informal alike, so as to fully realise the function of communication tools.

\section{Conclusions}

Specialised bilingual communication seems to have become an important part of Polish-Ukrainian language contacts, in particular on account of the tightening economic, scientific, technological and social cooperation between Poland and Ukraine. Moreover, new discoveries and developments, revised theories and new social phenomena require new names or reformulation of the definitions of existing ones. Terminological dictionaries in Ukrainian and Polish could potentially facilitate the uninterrupted flow of specialised knowledge, and hence professional communication.

Unfortunately, terminographic analysis of bi- and multilingual dictionaries in Polish and Ukrainian published in Poland to date has confirmed the general opinion that many dictionaries of particular fields are missing from the contemporary Polish-Ukrainian dictionary market. There are several fields of knowledge and professional activity, essential from the perspective of bilateral Polish-Ukrainian relations, requiring urgent terminographic intervention.

Similarly, there are a lot of specialised dictionary types that need terminographers' attention. In view of the increased interest of Ukrainians in learning and studying in Poland, didactic specialised dictionaries seem to be in short supply. This demand comes together with the need to increase the quality of dictionaries by consistently including those elements of macro- and microstructure that are expected by the users, such as definitions, word stress or illustration of term use. Dictionary quality is ensured at the very initial stages of dictionary compilation, namely dictionary design and studies of user needs. Later in the process, it consists of the collection 
of high quality source texts, including terminological or technical standards. In fact, it involves the creation of a specialised corpus for a particular terminographic project, balanced as regards formal, semi-formal and informal LSP variety. However, no dictionary analysed in this study seems to have been compiled based on corpus data or following user needs studies. Likewise, the market lacks contemporary terminographic tools, such as electronic and online dictionaries (none was registered by the author). Accordingly, a more modern and informed approach to specialised dictionary construction needs to be implemented in Polish-Ukrainian terminography.

On a final note, terminographic works of all types require a comprehensive theory that would ensure the high quality of the end product. Such a theory should include the descriptive, the parametric and the applicative element, and should enable terminographers to develop an optimum set of dictionary parameters. These parameters should be tailored to the needs of specific groups of users, meet the requirements of the terminographic theory (i.e. follow as closely as possible the parameters of the terminographic models) and make the work a viable and successful product on the dictionary market. However, such a theory in the area of Polish-Ukrainian terminography is yet to be formulated.

\section{Addendum: Terminographic analysis: summary data}

[1] Domagalski, S. (1994). Praktyczny polsko-rosyjsko-ukrainski słownik ekonomiczno-handlowy. Warszawa: Warszawski Dom Wydawniczy.

ISBN: 8385558020

Directionality: polyglot. $(\mathrm{pl}>\mathrm{ru}>\mathrm{uk})$

Field(s): trade, economics

No. of entries: approx. 15,000

Arrangement of entries: alphabetical

Dictionary type: glossary (hybrid)

Definitions: $+/-(\mathrm{pl}, \mathrm{ru}$, uk (see comments))

Word stress marks: -

Grammatical information: -

Bibliography: -

Indexes: -

Comments: Approximately 300 terms of the lemma stock have been defined in Polish, Russian and Ukrainian and presented in three consecutive appendices after the main body. Some entries offer illustration of term use.

[2] Wasiak, E., Zadorożna, S. (1995). Mały praktyczny słownik biznesmena ukraińsko-polski, polskoukrainski. Warszawa: Wydawnictwa Szkolne i Pedagogiczne.

ISBN: 8302055964

Directionality: $\mathrm{uk}>\mathrm{pl}, \mathrm{pl}>\mathrm{uk}$

Field(s): business

No. of entries: approx. $2000(\mathrm{uk}>\mathrm{pl}), 2000(\mathrm{pl}>\mathrm{uk})$

Arrangement of entries: alphabetical

Dictionary type: glossary

Definitions: -

Word stress marks: + (uk)

Grammatical information: + (gender)

Bibliography: -

Indexes: -

Comments: Some entries offer illustration of term use. 
$[3]$

Markunas, A., Uczitiel, T. (1995). Terminologia kościelna: mały słownik opisowy polsko-ukraiński i ukrainsko-polski. Poznań: Wydawnictwo Naukowe UAM.

ISBN: 8323206961

Directionality: $\mathrm{pl}>\mathrm{uk}, \mathrm{uk}>\mathrm{pl}$

Field(s): religious studies

No. of entries: $1300(\mathrm{pl}>\mathrm{uk}), 900(\mathrm{uk}>\mathrm{pl})$

Arrangement of entries: alphabetical

Dictionary type: explanatory

Definitions: $+(\mathrm{pl}, \mathrm{uk})$

Word stress marks: + (uk)

Grammatical information: -

Bibliography: +

Indexes: -

Comments: The lemma stock consists of a significant number of synonymous terms, constituting reference entries. The dictionary was followed by a more comprehensive Popularny słownik sakralizmów polskich i ukraińskich (Poznań, 2001) - see [7]. Addenda include prayers, presented in a parallel pl/uk fashion.

[4]

Szumiłowicz, G. (1999). Mały słownik terminologii medycznej: j. polski, j. łaciński, j. ukraiński. Szczecin: "Zapol".

ISBN: 8387377074

Directionality: polyglot. ( $\mathrm{pl}>\mathrm{la}>\mathrm{uk})$

Field(s): trade, economy

No. of entries: approx. 6,000

Arrangement of entries: alphabetical

Dictionary type: glossary

Definitions:

Word stress marks: -

Grammatical information: + (gender)

Bibliography: -

Indexes: -

Comments: -

[5]

Domagalski, S. (2000). Praktyczny stownik polsko-rosyjsko-ukrainski: ekonomika i handel ( $z$ indeksami terminów rosyjskich i ukraińskich). Warszawa: "Rea".

ISBN: 8371412967

Directionality: polyglot ( $\mathrm{pl}>\mathrm{ru}>\mathrm{uk})$

Field(s): trade, economics

No. of entries: approx. 32,000

Arrangement of entries: alphabetical

Dictionary type: glossary (hybrid)

Definitions: $+/-(\mathrm{pl}, \mathrm{ru}$, uk (see comments))

Word stress marks: -

Grammatical information: -

Bibliography: -

Indexes: $+(\mathrm{ru}>\mathrm{pl}, \mathrm{uk}>\mathrm{pl})$

Comments: Approximately 350 terms of the lemma stock have been defined in Polish, Russian and Ukrainian and presented in three consecutive appendixes after the main body (the terms defined are indicated by an asterisk in the main lemma list). Indexes are in the form of mini-glossaries, Russian-Polish and Ukrainian-Polish. The appendixes include list of world currencies and a small glossary of geographical names. 
[6]

Wojtowicz, Cz., Górska, R., Przybylski, L. (eds.); Dubovska, R. et al. (auth.) (2001). Basic terminology on machining with tools of defined wedge geometry: in eight languages (English, French, German, Polish, Russian, Ukrainian, Czech, Slovak)=Podstawowa terminologia z obróbki skrawaniem narzędziami o określonej geometrii ostrza: ośmiojęzyczna (angielski, francuski, niemiecki, polski, rosyjski, ukrainski, czeski, słowacki). Cracow: University of Technology.

ISBN: 8372421773

Directionality: polyglot. $(\mathrm{en}>\mathrm{pl}>\mathrm{fr}>\mathrm{de}>\mathrm{ru}>\mathrm{uk}>\mathrm{cs}>\mathrm{sk})$

Field(s): machining

No. of entries: 660

Arrangement of entries: systematic

Dictionary type: explanatory

Definitions: + (en, pl (see comments))

Word stress marks: -

Grammatical information: -

Bibliography: +

Indexes: + (en, pl)

Comments: With the dictionary offering definitions only in English and Polish, it seems to be is primarily designed for Polish users. However, acknowledging the role of English in international professional scientific and technical communication, the work can be regarded as a sum of bilingual English-otherlanguage dictionaries. The vocabulary stock is based on terminological standards and recommendations of CIRP - the International Institution for Production and Engineering Research.

$[7]$

Markunas, A., Uczitiel, T. (2001). Popularny słownik sakralizmów polskich i ukrainsskich. Poznań: Wydawnictwo Naukowe UAM.

ISBN: 8323210977

Directionality: $\mathrm{pl}>\mathrm{uk}, \mathrm{uk}>\mathrm{pl}$

Field(s): religious studies

No. of entries: approx. $1,500(\mathrm{pl}>\mathrm{uk}), 2,000(\mathrm{uk}>\mathrm{pl})$

Arrangement of entries: alphabetical

Dictionary type: explanatory

Definitions: $+(\mathrm{pl}, \mathrm{uk})$

Word stress marks: $+(\mathrm{uk})$

Grammatical information: -

Bibliography: +

Indexes: -

Comments: The dictionary is a corrected and expanded version of the previous work, titled Terminologia kościelna: mały słownik opisowy polsko-ukraiński i ukraińsko-polski (Poznań, 1995) — see [3]. Some meaning explanations are in the form of a list of synonymous terms.

$[8]$

Domagalski, S. (2002). Stownik biznesu ukrainsko-polski i polsko-ukraiński. Warszawa: Wiedza Powszechna.

ISBN: 832141236X

Directionality: $\mathrm{uk}>\mathrm{pl}, \mathrm{pl}>\mathrm{uk}$

Field(s): business

No. of entries: approx. $10000(\mathrm{uk}>\mathrm{pl}), 10000(\mathrm{pl}>\mathrm{uk})$

Arrangement of entries: alphabetical

Dictionary type: glossary

Definitions:

Word stress marks: -

Grammatical information: -

Bibliography: - 
Indexes: -

Comments: The appendixes include list of names of countries, capital cities and world currencies.

[9]

Kostčenko, A.V., Kostčenko, V.A. (2003). Mały słownik medyczny ukraińsko-polski i polskoukraiński. Kraków: „Secesja”.

ISBN: 8387345423

Directionality: $\mathrm{uk}>\mathrm{pl}, \mathrm{pl}>\mathrm{uk}$

Field(s): medicine

No. of entries: approx. $2000(\mathrm{uk}>\mathrm{pl}), 2400(\mathrm{pl}>\mathrm{uk})$

Arrangement of entries: alphabetical

Dictionary type: glossary

Definitions:

Word stress marks: -

Grammatical information: -

Bibliography: -

Indexes: -

Comments: -

[10]

Zięba, M. (ed.), Bielak, A. et al. (auth.) (2004). Polsko-ukraiński, ukraińsko-polski glosariusz terminów administracji publicznej. Lublin: Fundacja Młoda Demokracja.

ISBN: 8392153669

Directionality: $\mathrm{pl}>\mathrm{uk}, \mathrm{uk}>\mathrm{pl}$

Field(s): public administration

No. of entries: approx. 950

Arrangement of entries: thematic

Dictionary type: glossary (hybrid)

Definitions: $+/-(\mathrm{pl}$, uk (see comments $))$

Word stress marks: -

Grammatical information: -

Bibliography: -

Indexes: $+(\mathrm{pl}, \mathrm{uk})$

Comments: The dictionary is divided into 20 thematic sections. Some entries, especially in sections no. $1,2,3,4,5$ and 6 have been defined in Polish and Ukrainian (in respective language parts). Other terms lack explanations. Tags indicate the political reality, to which a particular term refers to, i.e. that of the European Union, Poland or Ukraine. The website to which the authors refer to for an expanded list of vocabulary (www.ebug.pl) is not online anymore. A CD-ROM version has been added to the dictionary (was not analysed by the author).

[11]

Alekseenko, M.A., Alksnko, M., Gornâtko-Šumilovič, A., Horniatko-Szumiłowicz, A. (2005). Ukraińsko-polski słownik terminów lingwistycznych. Szczecin: Wydawnictwo Naukowe Uniwersytetu Szczecińskiego.

ISBN: 8372414416

Directionality: $\mathrm{uk}>\mathrm{pl}$

Field(s): linguistics

No. of entries: approx. 7,300

Arrangement of entries: alphabetical

Dictionary type: glossary

Definitions: -

Word stress marks: + (uk)

Grammatical information: + (gender; word endings for genitive case; word forms for feminine and neuter of adjectives) 
Bibliography: +

Indexes: -

Comments: -

[12]

Kozubel, W. (2006). Słownik terminów biologicznych ukraińsko-polski i polsko-ukraiński, Warszawa: Wydawnictwa Szkolne i Pedagogiczne.

ISBN: 9788302097003

Directionality: uk $>\mathrm{pl}, \mathrm{pl}>\mathrm{uk}$

Field(s): biology

No. of entries: approx. $2,500(\mathrm{uk}>\mathrm{pl}), 2,500(\mathrm{pl}>\mathrm{uk})$

Arrangement of entries: alphabetical

Dictionary type: glossary

Definitions: -

Word stress marks: + (uk)

Grammatical information: -

Bibliography: +

Indexes: -

Comments: The dictionary has been listed as supplementary reference work by the Polish Ministry of Education for classes with Ukrainian as the language of instruction.

[13]

Wasyluk, A., Maciej Tanaś, M (2006). Leksykon pedagogiczny angielsko-polsko-ukraiński. Płock: Oficyna Wydawnicza Szkoły Wyższej im. Pawła Włodkowica - Wydawnictwo Naukowe Novum.

ISBN: 8389416891

Directionality: polyglot. (en>pl>uk)

Field(s): pedagogics

No. of entries: approx. 1,200

Arrangement of entries: alphabetical

Dictionary type: glossary (hybrid)

Definitions: $+/-($ uk (see comments))

Word stress marks: -

Grammatical information: -

Bibliography: +

Indexes: -

Comments: The dictionary is a revised version of the two previous dictionaries by A. Vasiluk, namely Педагогічний словник-лексикон. Англо-українсъкий. Украӥнсъко-англійський (Ні́жин, 2004) and Нові педагогічні поняття: англо-польсъко-українсъкий словник (Ні́жин, 1999). The vocabulary stock also includes selected terminology of methodology, philosophy, psychology and information science. The dictionary consists of four parts: (1) English-Polish-Ukrainian dictionary of terms - with definitions (most terms have been defined) provided in Ukrainian; (2) English-Polish-Ukrainian dictionary of international organisations related to teaching; (3) Polish-English-Ukrainian glossary of terms; (4) Ukrainian-EnglishPolish glossary of terms.

[14]

Ojcewicz G. et al. (2006). Praktyczny słownik policyjno-prawniczy: polski, białoruski, litewski, rosyjski, ukrainski. Szczytno: Wyższa Szkoła Policji.

ISBN: 9788374620628

Directionality: polyglot. ( $\mathrm{pl}>\mathrm{be}>\mathrm{lt}>\mathrm{ru}>\mathrm{uk})$

Field(s): law, police

No. of entries: approx. 5,400

Arrangement of entries: alphabetical

Dictionary type: glossary

Definitions: - 
Word stress marks: + (be, lt, ru, uk)

Grammatical information: + (gender)

Bibliography: -

Indexes: -

Comments: Neologisms have been marked with an asterisk. The dictionary also includes slang expressions.

$[15]$

Kozubel, W. (2007). Słownik terminów chemicznych ukraińsko-polski i polsko-ukraiński. Warszawa: Wydawnictwa Szkolne i Pedagogiczne.

ISBN: 9788302098499

Directionality: $\mathrm{uk}>\mathrm{pl}, \mathrm{pl}>\mathrm{uk}$

Field(s): chemistry

No. of entries: approx. 2,000 (uk>pl), 2,000 ( $\mathrm{pl}>\mathrm{uk})$

Arrangement of entries: alphabetical

Dictionary type: glossary

Definitions:

Word stress marks: + (uk)

Grammatical information: -

Bibliography: +

Indexes: -

Comments: The dictionary includes systematic names in accordance with the IUPAC recommendations, but also trivial names (being reference entries in the dictionary). Ukrainian names of elements and chemical compounds are in accordance with the recommendations of the Ukrainian National Committee in Chemical Nomenclature and Terminology. The addenda to the dictionary include ( $\mathrm{uk}>\mathrm{pl}$ ): base and derived SI units; prefixes of the power of ten; standardized names of elements. The dictionary has been listed as supplementary reference work by the Polish Ministry of Education for classes with Ukrainian as the language of instruction.

[16]

Bratyczak, M., Romaško, I., Żmudzińska-Żurek, B. (2007). Angielsko-polsko-rosyjsko-ukraiński słownik z chemii i technologii ropy naftowej. Kraków: Instytut Technologii Nafty im. Stanisława Pilata.

ISBN: 9788392578802

Directionality: polyglot. (en $>$ pl $>$ ru $>$ uk)

Field(s): chemistry, oil refining

No. of entries: 2966

Arrangement of entries: alphabetical

Dictionary type: glossary

Definitions: -

Word stress marks: -

Grammatical information: -

Bibliography: -

Indexes: $+(\mathrm{pl}, \mathrm{ru}, \mathrm{uk})$

Comments: -

[17]

Domagalski, S. (2008). Wielki słownik polsko-ukraiński, ukraińsko-polski: z rozszerzona terminologia wspótczesnego biznesu: 200000 wyrażeń. Warszawa: Wydawnictwo Rea.

ISBN: 9788371417504

Directionality: $\mathrm{pl}>\mathrm{uk}, \mathrm{uk}>\mathrm{pl}$

Field(s): business

No. of entries: 40,000 (pl>uk); 40,000 (uk>pl)

Arrangement of entries: alphabetical 
Dictionary type: glossary

Definitions: -

Word stress marks: -

Grammatical information: -

Bibliography: -

Indexes: -

Comments: The dictionary registers a significant number of business terms. The appendixes include list of names of countries, capital cities and world currencies and a small glossary of geographical names

[18]

Halan, W. (2008). Słownik terminów informatycznych ukrainssko-polski i polsko-ukraiński. Warszawa: Wydawnictwa Szkolne i Pedagogiczne .

ISBN: 9788302103155

Directionality: $\mathrm{uk}>\mathrm{pl}, \mathrm{pl}>\mathrm{uk}$

Field(s): information technology

No. of entries: approx. $6,000(\mathrm{uk}>\mathrm{pl}), 6,000(\mathrm{pl}>\mathrm{uk})$

Arrangement of entries: alphabetical

Dictionary type: glossary

Definitions:

Word stress marks: + (uk)

Grammatical information: -

Bibliography: +

Indexes: -

Comments: The dictionary has been listed as supplementary reference work by the Polish Ministry of Education for classes with Ukrainian as the language of instruction.

[19]

Ojcewicz, G. et al. (2009). Podręczny słownik administracji: polski, białoruski, litewski, rosyjski, ukraiński. Szczytno: Wydawnictwo Wyższej Szkoły Policji. Wydział Wydawnictw i Poligrafii.

ISBN: 9788374621861

Directionality: polyglot. ( $\mathrm{pl}>\mathrm{be}>\mathrm{lt}>\mathrm{ru}>\mathrm{uk})$

Field(s): administration

No. of entries: approx. 6,200

Arrangement of entries: alphabetical

Dictionary type: glossary

Definitions:

Word stress marks: + (be, lt, ru, uk)

Grammatical information: -

Bibliography: -

Indexes: -

Comments: Despite title similarity, the glossary is not a copy of its 2008 predecessor, namely Podręczny słownik administracji: polski, angielski, francuski, niemiecki, rosyjski.

$[20]$

Kuczyńska, M. et al. (2010). Polsko-czesko-rosyjsko-ukraiński słownik pojęć literackich. Szczecin: Volumina.pl, Daniel Krzanowski.

ISBN: 9788362355099

Directionality: polyglot. $(\mathrm{pl}>\mathrm{cs}>\mathrm{ru}>\mathrm{uk})$

Field(s): literary studies

No. of entries: approx. 4,000

Arrangement of entries: alphabetical

Dictionary type: glossary

Definitions:

Word stress marks: + (uk, ru) 
Grammatical information: + (gender; word endings for genitive case)

Bibliography: +

Indexes: $+(\mathrm{pl})$

Comments: The index of Polish terms (sic!) includes only approx. 1,900 main headwords (of the 4,000 entries).

[21]

Domagalski, S. (2014) Wielki słownik polsko-ukrainski, ukraińsko-polski: z rozszerzona terminologia wspótczesnego biznesu: 200000 wyrażeń, Warszawa: Wydawnictwo Rea.

ISBN: 9788379930425

Directionality: pl $>\mathrm{uk}, \mathrm{uk}>\mathrm{pl}$

Field(s): business

No. of entries: 40,000 (pl>uk); 40,000 (uk>pl)

Arrangement of entries: alphabetical

Dictionary type: glossary

Definitions: -

Word stress marks: -

Grammatical information: -

Bibliography: -

Indexes: -

Comments: Second impression of the 2008 dictionary by the same autor - see [17]. The work registers a significant number of business terms. The appendixes include list of names of countries, capital cities and world currencies and a small glossary of geographical names

$[22]$

Kaczmarczyk, M., Nowacki, A. (2015) Polsko-ukraiński słownik terminów dziennikarskich: z suplementem ukrainsko-polskim, Lublin: Wydawnictwo KUL.

ISBN: 9788380610149

Directionality: pl>uk

Field(s): journalism

No. of entries: 734

Arrangement of entries: alphabetical

Dictionary type: explanatory

Definitions: $+(\mathrm{pl})$

Word stress marks: $+(\mathrm{uk})$

Grammatical information: + (gender; word endings for genitive case)

Bibliography: +

Indexes: $+(\mathrm{uk}>\mathrm{pl})$

Comments: Simplified pronunciation guide is provided for internationalisms.

\section{References}

Alekseenko, M., \& Gornâtko-Šumilovič, A. (2005). Ukraińsko-polski słownik terminów lingwistycznych. Szczecin: Wydawnictwo Naukowe Uniwersytetu Szczecińskiego.

Bańko, M. (1988). Porządek alfabetyczny jako narzędzie pracy leksykografa. In Z. Saloni (Ed.), Studia z polskiej leksykografii współczesnej (Vol. 2, pp. 57-72). Białystok: Dział Wydawnictw Filii UW.

Barwiak, A. (2005). Terminologia ekonomiczna we współczesnym ukraińskim języku literackim (Unpublished Master's thesis). John Paul II Catholic University of Lublin, Lublin.

Bergenholtz, H., \& Tarp, S. (1995). Manual of specialised lexicography. Amsterdam: John Benjamins.

Bibliography of dictionaries published in Bulgarian People's Republic, Chinese People's Republic, Czechoslovak Socialist Republic, German Democratic Republic, Hungarian People's Republic, Polish People's Republic, Rumanian People's Republic, Union of Soviet Socialist Republics, 1945-1961. (1965). Warszawa: Wydawnictwa Naukowo-Techniczne. 
Bibliography of dictionaries published in Bulgarian People's Republic, Chinese People's Republic, Czechoslovak Socialist Republic, German Democratic Republic, Hungarian People's Republic, Polish People's Republic, Rumanian People's Republic, Socialist Federal Republic of Yugoslavia, Union of Soviet Socialist Republics, 1962-1964. (1968). Warszawa: Wydawnictwa Naukowo-Techniczne.

Bibliography of dictionaries published in Bulgarian People's Republic, Chinese People's Republic, Czechoslovak Socialist Republic, German Democratic Republic, Hungarian People's Republic, Korean People's Democratic Republic, Polish People's Republic, Rumanian People's Republic, Socialist Federal Republic of Jugoslavia, Union of Soviet Socialist Republics, 1965-1966. (1969). Warszawa: Wydawnictwa Naukowo-Techniczne.

Bibliography of dictionaries published in Bulgarian People's Republic, Czechoslovak Socialist Republic, German Democratic Republic, Hungarian People's Republic, Polish People's Republic, Rumanian People's Republic, Union of Soviet Socialist Republics, 1967-1968. (1970). Warszawa: Wydawnictwa Naukowo-Techniczne.

Bibliography of dictionaries published in Bulgarian People's Republic, Czechoslovak Socialist Republic, German Democratic Republic, Hungarian People's Republic, Polish People's Republic, Rumanian Socialist Republic, Union of Soviet Socialist Republics, 1969-1970. (1972). Warszawa: Wydawnictwa Naukowo-Techniczne.

Bibliography of dictionaries published in Bulgarian People's Republic, Czechoslovak Socialist Republic, German Democratic Republic, Hungarian People's Republic, Polish People's Republic, Rumanian Socialist Republic, Union of Soviet Socialist Republics, 1971-1972. (1974). Warszawa: Wydawnictwa Naukowo-Techniczne.

Bibliography of dictionaries published in Bulgarian People's Republic, Czechoslovak Socialist Republic, German Democratic Republic, Hungarian People's Republic, Polish People's Republic, Rumanian Socialist Republic, Union of Soviet Socialist Republics, 1973-1974. (1976). Warszawa: Wydawnictwa Naukowo-Techniczne.

Bibliography of dictionaries published in Bulgarian People's Republic, Czechoslovak Socialist Republic, German Democratic Republic, Hungarian People's Republic, Polish People's Republic, Rumanian Socialist Republic, Union of Soviet Socialist Republics, 1975-1976. (1978). Warszawa: Wydawnictwa Naukowo-Techniczne.

Bibliography of dictionaries published in Bulgarian People's Republic, Czechoslovak Socialist Republic, German Democratic Republic, Hungarian People's Republic, Polish People's Republic, Rumanian Socialist Republic, Union of Soviet Socialist Republics, 1977-1978. (1981). Warszawa: Wydawnictwa Naukowo-Techniczne.

Bogusławski, A. (1988). Dwujęzyczny słownik ogólny: Projekt instrukcji z komentarzami. In Z. Saloni (Ed.), Studia z polskiej leksykografii współczesnej (Vol. 1, pp. 19-65). Wrocław: Zakład Narodowy im. Ossolińskich, Wydawnictwo PAN.

Bratyczak, M., Romaško, I., \& Żmudzińska-Żurek, B. (2007). Angielsko-polsko-rosyjsko-ukraiński słownik z chemii $i$ technologii ropy naftowej. Kraków: Instytut Technologii Nafty im. Stanisława Pilata.

Czerni, S. (1977). Stowniki specjalistyczne. Warszawa: WNT.

Czobot, E. (1999). Terminologia ekonomiczna we wspótczesnym języku ukraińskim (Unpublished Master's thesis). John Paul II Catholic University of Lublin, Lublin.

Domagalski, S. (1994). Praktyczny polsko-rosyjsko-ukraiński słownik ekonomiczno-handlowy. Warszawa: Warszawski Dom Wydawniczy.

Domagalski, S. (2000). Praktyczny słownik polsko-rosyjsko-ukraiński: Ekonomika i handel (z indeksami terminów rosyjskich i ukraińskich). Warszawa: "Rea".

Domagalski, S. (2002). Stownik biznesu ukraińsko-polski i polsko-ukraiński. Warszawa: Wiedza Powszechna.

Domagalski, S. (2008). Wielki słownik polsko-ukraiński, ukraińsko-polski: Z rozszerzona terminologia współczesnego biznesu: 200000 wyrażen. Warszawa: Wydawnictwo Rea.

Domagalski, S. (2014) Wielki słownik polsko-ukraiński, ukraińsko-polski: Z rozszerzona terminologia wspótczesnego biznesu: 200000 wyrażen. Warszawa: Wydawnictwo Rea.

Draus, J. (2011). Polish-Ukrainian relations after independence. Political Science/New Ukraine - Nowa Ukraina, (11), 55-72.

Felber, H., \& Budin, G. (1994). Teoria i praktyka terminologii. Warszawa: Wydawnictwa Uniwersytetu Warszawskiego. 
Goetting, M. (2015, March 24). Poland sees sharp rise in Ukrainian immigrants amid conflict. Reuters. Retrieved 10 June 2016, from http://www.reuters.com/article/2015/03/24/ us-ukraine-crisis-poland-immigration-idUSKBNOMK12H20150324

Grzegorczyk, P. (1967). Index Lexicorum Poloniae: Bibliografia słowników polskich. Warszawa: Państwowe Wydawnictwo Naukowe.

Halan, W. (2008). Słownik terminów informatycznych ukraińsko-polski i polsko-ukraiński. Warszawa: Wydawnictwa Szkolne i Pedagogiczne.

Jóźwikiewicz, P. (2013). Lingua Ucraina ad res informaticas pertinens: Studium nad ukraińskim słownictwem informatycznym. Wrocław: Wydawnictwo Uniwersytetu Wrocawskiego.

Kaczmarczyk, M., \& Nowacki, A. (2015) Polsko-ukraiński słownik terminów dziennikarskich: Z suplementem ukraińsko-polskim. Lublin: Wydawnictwo KUL.

Kępa, D. (2005). Wspótczesna terminologia ukraińska z zakresu prawa międzynarodowego (Unpublished Master's thesis). John Paul II Catholic University of Lublin, Lublin.

Komova, M. (2003). Ukrajins'ka terminohrafija (1948-2002). L'viv: Liha-Pres.

Kononenko, I., Mytnik, I., \& Wasiak, E. (2010). Stownik tematyczny polsko-ukraiński. Warszawa: PWN. (Dodruk 2015)

Kostčenko, A. V., \& Kostčenko, V. A. (2003). Mały słownik medyczny ukraińsko-polski i polsko-ukraiński. Kraków: „Secesja”.

Kotsyba, N., \& Turska, M. (2006). Leksykografia polsko-ukraińska — stan obecny i perspektywy. In V. Koseska-Toszewa \& R. Roszko (Eds.), Semantyka a konfrontacja językowa (Vol. 3, pp. 69-101). Warszawa: Slawistyczny Ośrodek Wydawniczy PAN. Retrieved 10 June 2016, from http://www. domeczek.pl/ natko/papers/dict-pl-ua_kotsyba-turska.pdf

Kozubel, W. (2006). Słownik terminów biologicznych ukraińsko-polski i polsko-ukraiński. Warszawa: Wydawnictwa Szkolne i Pedagogiczne.

Kozubel, W. (2007). Stownik terminów chemicznych ukraińsko-polski i polsko-ukraiński. Warszawa: Wydawnictwa Szkolne i Pedagogiczne.

Kuczyńska, M. et al. (2010). Polsko-czesko-rosyjsko-ukraiński słownik pojęć literackich. Szczecin: Volumina.pl, Daniel Krzanowski.

Kuspys, P. (2008). Współpraca gospodarcza Polski i Ukrainy. Gospodarka Narodowa, (4), 41-57.

Lukszyn, J. (2010). Słownik przedmiotowy jako tekst edukacyjny. In S. Grucza, M. Płużyczka, \& A. Marchwiński (Eds.), Translatoryka: Koncepcje — modele — analizy (pp. 92-98). Warszawa: Wydział Lingwistyki Stosowanej, Uniwersytet Warszawski.

Lukszyn, J., \& Zmarzer, W. (2006). Teoretyczne podstawy terminologii. Warszawa: Katedra Języków Specjalistycznych UW.

Łukasik, M. (2007). Angielsko-polskie i polsko-angielskie słowniki specjalistyczne (1990-2006): Analiza terminograficzna. Warszawa: Katedra Języków Specjalistycznych UW.

Łukasik, M. (2010). Teksty specjalistyczne a konstruowanie terminograficzne (Unpublished PhD thesis). Wydział Lingwistyki Stosowanej UW, Warszawa.

Łukasik, M. (2014). Terminological dictionary as a comprehensive cognitive and linguistic tool. Language in Different Contexts: Research Papers, 5(1), 98-108.

Markunas, A., \& Uczitiel, T. (1995). Terminologia kościelna: mały słownik opisowy polsko-ukraiński $i$ ukraińsko-polski. Poznań: Wydawnictwo Naukowe UAM.

Markunas, A., \& Uczitiel, T. (2001). Popularny słownik sakralizmów polskich i ukraińskich. Poznań: Wydawnictwo Naukowe UAM.

Michta, T. (2014). Słownik jako model wiedzy. In T. Michta (Ed.), Narzędzia pracy lingwistycznej (pp. 171-198). Warszawa: Instytut Rusycystyki, Wydział Lingwistyki Stosowanej UW.

Ministerstwo Edukacji Narodowej. (n.d.). Wykaz podręczników szkolnych i książek pomocniczych przeznaczonych dla mniejszości narodowych, mniejszości etnicznych oraz społeczności posługującej się językiem kaszubskim, dopuszczonych po 10 marca 1999 r. Retrieved 10 June 2016, from https: //archiwum.men.gov.pl/index $\cdot$ php?option=com_content\&view=article\&id=2230

Ojcewicz, G. et al. (2006). Praktyczny słownik policyjno-prawniczy: Polski, białoruski, litewski, rosyjski, ukraiński. Szczytno: Wyższa Szkoła Policji.

Ojcewicz, G. et al. (2009). Podręczny słownik administracji: Polski, białoruski, litewski, rosyjski, ukraiński. Szczytno: Wydawnictwo Wyższej Szkoły Policji. Wydział Wydawnictw i Poligrafii.

Piotrowski, T. (2001). Zrozumieć leksykografię. Warszawa: Wydawnictwo Naukowe PWN. 
PL-BY-UA 2007-2013: Cross-Border Cooperation Programme: Poland - Belarus - Ukraine 2007-2013 (PL-BY-UA 2007-2013). (n.d.). Retrieved 10 June 2016, from https://www.cpe.gov.pl/pliki/127-plby-ua-eng-5b1-5d.pdf

Pliszka, A. (2010). Charakterystyka strukturalno-semantyczna terminologii prawniczej $w$ języku polskim $i$ ukraińskim (Unpublished Master's thesis). John Paul II Catholic University of Lublin, Lublin.

Polish Press Agency. (2014). Polish-Ukrainian trade exchange and the current political crisis in Ukraine. Retrieved 10 June 2016, from http://msp.gov.pl/en/polish-economy/economic-news/ 5296, Polish-Ukrainian-trade-exchange-and-the-current-political-crisis-in-Ukraine.pdf

Polsko-ukraiński słownik elektroniczny. (n.d.). Retrieved 20 August 2015, from http://www.domeczek. $\mathrm{pl} / \sim \mathrm{polukr} / \mathrm{pus} /$ index.php

Ruda, O. (2012). Translational terminological dictionaries of the 20th century (1945-1999). XLinguae Journal, 5(4), 16-28.

Rudnickyj, J. B. (1991). Ukrainian lexicography. In F. J. Hausmann et al. (Eds.), Dictionaries: An international encyclopedia of lexicography (pp. 2329-2335). Berlin: Walter de Gruyter.

Shcherba, H. (2013). Cross-Border cooperation between Ukraine and Poland under condition of financial crisis. Nierówności społeczne a wzrost gospodarczy, (30), 348-353.

Szumiłowicz, G. (1999). Mały słownik terminologii medycznej: J. polski, j. łaciński, j. ukraiński. Szczecin: "Zapol".

Szuper-Jakubiuk, D. (2010). Bibliografia słowników przekładowych handlowych i okołohandlowych (język polski, rosyjski, ukraiński) za lata 1990-2010 w układzie chronologicznym. Linguodidactica, 14, 243240 .

Tarp, S. (2012). Specialised lexicography: 20 years in slow motion. Ibérica, 24, 117-128.

Wasiak, E., \& Zadorożna, S. (1995). Maty praktyczny słownik biznesmena ukraińsko-polski, polsko-ukraiński. Warszawa: Wydawnictwa Szkolne i Pedagogiczne.

Wasyluk, A., \& Tanaś, M. (2006). Leksykon pedagogiczny angielsko-polsko-ukraiński. Płock: Oficyna Wydawnicza Szkoły Wyższej im. Pawła Włodkowica.

Wojtowicz, C., Górska, R., Przybylski, L. (Eds.), Dubovska, R. et al. (Auth.). (2001). Basic terminology on machining with tools of defined wedge geometry: In eight languages (English, French, German, Polish, Russian, Ukrainian, Czech, Slovak) [Podstawowa terminologia z obróbki skrawaniem narzędziami o określonej geometrii ostrza: Ośmiojęzyczna (angielski, francuski, niemiecki, polski, rosyjski, ukraiński, czeski, słowacki)]. Cracow: University of Technology.

Zięba, M. (Ed.), Bielak, A. et al. (Auth.) (2004). Polsko-ukraiński, ukraińsko-polski glosariusz terminów administracji publicznej. Lublin: Fundacja Młoda Demokracja.

\section{Acknowledgment}

This work was supported by a core funding for statutory activities from the Polish Ministry of Science and Higher Education.

The author declares that he has no competing interests.

This is an Open Access article distributed under the terms of the Creative Commons Attribution 3.0 PL License (http://creativecommons.org/licenses/by/3.0/pl/), which permits redistribution, commercial and noncommercial, provided that the article is properly cited.

(C) The Author 2016

Publisher: Institute of Slavic Studies, Polish Academy of Sciences, University of Silesia \& The Slavic Foundation 